\title{
Adaptation and identity shifts after migration and return migration: Turkish qualified returnees from Germany and the US
}

\author{
Meltem Yilmaz Sener ${ }^{ \pm}$
}

\begin{abstract}
This study looks at the adaptation experiences of Turkish qualified migrants who returned to Turkey after living in Germany and the US, discussing their identity shifts both during the period spent in the host country and after the return. I look at their i- pre-migration familiarity with the language and culture of the host country, ii-social groups in the host country, iii- association memberships in the host country, iv-frequency of their visits to Turkey, $v$ - the extent to which they followed the developments in Turkey, vi-reasons behind the decision to return, vii-re-adaptation to the home country culture after return, and viii- relationships with other returnees and host country nationals after return. By focusing on these aspects of their experiences, I aim to demonstrate the kinds of orientations they have had to the host and home country cultures, and the identity shifts they had both after migration and return. I also discuss whether there are any differences between the returnees from Germany and the US in terms of these dimensions.
\end{abstract}

Keywords: return migration; adaptation; identity shift; qualified migrant; Turkish; Germany; the US.

\section{Introduction}

One's culture is a primary component and influencer of his/her identity. As Berry (1980) suggested, culture gives a frame of reference for self-definition and ordering of social relationships. After an experience of international migration, where the person leaves the culture of the home country and encounters a new culture, changes in identity are also expected. In his seminal work, Berry (1980) looks at how individuals from one cultural context adapt to a new context after migration. He uses the concept acculturation to refer to the cultural changes that emerge because of these encounters and identifies four different acculturation strategies (Berry, 1980:211-280).

Berry stresses that Integration as a strategy can only be valid for societies that are explicitly multicultural and in which certain preconditions are established; there should be a positive multicultural ideology, low levels of prejudice, positive mutual attitudes among cultural groups, and identification with the larger society by all groups (1980:11). Therefore, acculturation strategies are not freely chosen by the members of the migrant group, but contextual factors related to the host country also have an impact on the kind of strategy adopted. Berry also uses the concepts

${ }^{ \pm}$Meltem Yilmaz Sener, PhD, Associate Professor at Nord University, Universitetsalléen 11, 8026 Bodø, Norway. E-mail: yilmazmeltem@hotmail.com.

Acknowledgements: I would like to thank Gonca Türgen for her assistance and support throughout the research process, and İbrahim Sirkeci for his useful comments.

I would like to add funding information: This research was supported by TUBITAK (The Scientific and Technological Research Council of Turkey) Grant 1001, Project No: 114K685. Meltem Yilmaz Sener was the Principle Investigator for the Project. 


\section{Turkish qualified returnees from Germany and the US}

psychological acculturation and adaptation to talk about the psychological changes and final outcomes experienced after acculturation. Through psychological acculturation, individuals gain a new behavioural repertoire which is suitable for the new cultural context. However, a conflict occurs when there are incompatible behaviours suggested by home and host country cultures. Finally, adaptation refers to the changes in individuals or groups because of the contextual demands. "Sometimes there is increased "fit" between the acculturating individual and the new context... Other times, however, a "fit" is not achieved and the groups settle into a pattern of conflict, with resultant acculturative stress or psychopathology." (1980:14).

There are some early influential studies on return migration (Cerase, 1974), and some important debates emerged on return migration after the 1980s (Cassarino, 2004; Gmelch, 1980: Guzzetta, 2004; Mazzucato, 2007). However, in the literature, re-adaptation after return migration has received less attention than the process of adaptation after migration. In fact, many studies demonstrate that a lot of difficulties are experienced during re-adaptation after returning to one's own country (Adler, 1981; Chamove and Soeterik, 2006; Thompson and Christofi, 2006; Morgan, Nie, and Young, 2004; Linehan and Scullion, 2002; Stroh, Gregersen, and Black, 1998; Furukawa, 1997; Sahin 1990; Martin 1984). Black et al. (1992) argue that as many as $70 \%$ of the returnees have significant problems due to their return. Reverse culture shock (Presbitero, 2016; Allison et al.,2012; Baruch and Altman, 2002; Bossard and Peterson, 2005; Rodrigues, 2001; Huff, 2001; Gaw, 2000), repatriation stress/distress (Sussman, 2007, 2002, 2000; Herman and Tetrick, 2009), and adjustment stress (Weaver, 1993) are some of the concepts that scholars use to address the difficulties during re-adaptation.

Arguing that Berry's acculturation model (Berry et al., 1992; Berry 2005, 2001, 1997) can better explain permanent rather than temporary cultural contact, Sussman $(2007,2002,2000)$ developed the cultural identity model to explain return migration processes of sojourners or temporary migrants and to focus on their identity shifts after return. Sussman argues that four types of identity shift might occur, which are subtractive, additive, affirmative, and intercultural shifts. When there is a subtractive identity shift, the repatriates/returnees feel less content with the home country's culture, and they don't feel similar to their fellow citizens. They may try to seek other returnees to socialise with, as they find the values and behaviours of other nationals different from theirs. When an additive identity shift is experienced, returnees feel more comfortable with the culture of the host society, feeling at more ease with the values, norms, and behaviours of the host culture. Those returnees who have an additive shift seek out opportunities to interact with the members of the host culture. With both of these identity shifts, there is isolation from and limited interaction with the home country culture. The returnee feels that there is a very low level of fit with the nationals. When there is an affirmative identity shift, home culture identity is maintained and reinforced after the return. Individuals who have this type of shift have a low level of adaptation to the host culture.

Therefore, cultural self-concept is not altered significantly. "For affirmative sojourners who neither adapted successfully overseas nor experienced an identity change, researchers predicted that repatriation comes as a welcome relief." (Sussman, 2000: 367) Upon return/repatriation, they have an increased identification with the home country nationals. Finally, the intercultural or global identity shift, which is a less common one, makes it possible for the returnees/ repatriates to have multiple cultural scripts at the same time, and "draw on each as the working self-concept requires" (Sussman, 2000: 367). In this case, the repatriates/returnees have the kind of identity in which they 
define themselves as world citizens, and they can interact successfully in many different cultural contexts. Consequently, according to Sussman, the kind of identity shift has a major influence on the re-adjustment process: For the individuals who have additive or subtractive identity shifts, awareness of their identity change is a source of stress and they have difficulties readjusting, whereas those who have affirmative or intercultural/global identity shifts have less distress and have an easier experience of readjusting to the home country.

This study examines the adaptation experiences of Turkish qualified migrants who returned to Turkey after living in Germany and the US, discussing their identity shifts both during the period spent in the host country and after their return. I examine their a) pre-migration familiarity with the language and culture of the host country, b) social groups in the host country, d) association memberships in the host country, e) frequency of their visits to Turkey, f) the extent to which they followed the developments in Turkey, g) reasons behind the decision to return, $\mathrm{h}$ ) re-adaptation to the home country culture after return, and i) relationships with other returnees and host country nationals after return. By focusing on these aspects of their experiences, I aim to demonstrate the kinds of orientations they have had to the host and home country cultures, and the identity shifts they had both after migration and return. I also discuss whether there are any differences between the returnees from Germany and the US in terms of these dimensions.

In this article, I will mainly use Berry's acculturation model for discussing the strategies during the period of migration, and especially Sussman's framework for looking at the identity changes after the return. I will also try to demonstrate how the strategies the migrants had during the period of migration have an impact on the kinds of identity changes after their return migration. Although I will benefit from these theoretical frameworks, this study challenges those studies in at least two ways: 1) These frameworks assume that home and host country cultures are totally distinct, mutually exclusive entities, and migrants first encounter the new culture after their migration. However, even before migration, many individuals may have some components of the host country culture as part of their identities due to previous contacts with the host country culture. 2) These works mostly talk about the orientation towards either home or host country cultures. Yet, many migrants say that during their stay in the host country, they mostly socialised with other foreigners (not necessarily co-nationals) living in the same country. This implies that rather than conforming to the home or host country cultures, these individuals create/engage in a third cultural sphere, which is in the host country but different from the mainstream culture of the host society. It may include elements form a variety of cultures. There is a body of literature which looks at the third culture kids (Moore and Barker, 2012; Walters and Auton-Cuff, 2009; Cockburn, 2002; Dewaele and van Oudenhoven, 2009; Fail et al., 2004; Pollock and van Reken, 1999; Langford, 1998; Useem and Downie, 1976; or the kids who grow up abroad with their parents. However, in a different way from that literature, the current study will use third culture to refer to the cultural sphere that is created by the interaction of migrants from several different countries.

\section{Emigration from Turkey to Germany and the US}

According to Abadan-Unat (2011), there were five stages of Turkish emigration to Europe, particularly to Germany, between the 1950s and 2000s. i- During the 1950s, Turkish workers were invited by individuals to work in West Germany. There were small groups of technical high school graduates, mainly men aged between 20 and 35, who were invited to Germany as trainees for specified periods of time (Abadan-Unat, 1964; Akgündüz, 1993; Penninx, 1982). Individual 


\section{Turkish qualified returnees from Germany and the US}

enterprises and private agents played a major role during this early stage of Turkish migration to Germany. ii- 1960s was the period of migration based on official agreements between states, and the "guest worker" replaced the individual immigrant during this decade. On the Turkish side, population control and "export of surplus labour" was one of the targets of the First Five Year Development Plan. iii- During the 1970s, because of the economic crisis, European governments stopped accepting foreign labour. There was a significant decline in the number of work permits given to foreign workers, but the number of Turkish immigrants continued to increase because of family unifications. iv- During the 1980s, there was a rise in asylum applications after the military coup in Turkey. This was also the time when the "Foreigners Repatriation Incentive" law was introduced to encourage the return of Turkish (as well as other foreign) workers to their homeland. "This law led to a 5.4 per cent fall in the Turkish immigrant population in 1984, as approximately 250,000 returned to Turkey." (Abadan-Unat, 2011). Gitmez (1983) also estimates that during 1975 and 1976, annual returns ranged between 55,000 and 60,000, and until 1980, it was about 15,000 to 20,000 people. However, during the early 1980 s, it exceeded 70,000 people annually. v- AbadanUnat (2011) defines the 1990s as the period when Turkish immigrant workers kept on struggling to secure proper legal status for themselves, while the rise of xenophobia also had a big influence on their lives.

Sirkeci (2005) argues that Turkish migrations in the $20^{\text {th }}$ century conform to four major types: 1) individual migrations motivated by personal reasons; 2 ) compulsory migrations of especially the non-Muslim minority populations; 3) mass labour migrations especially between 1961 and 1980; 4) irregular migrations, which involved large numbers of asylum seekers and illegal migration after the military coup in 1980, and Kurdish migration due to the armed clashes between the Turkish Army and the Kurdistan Workers' Party (PKK).

As a result of consecutive phases of out-migration from Turkey, almost $7 \%$ of the current population has left the country during the last five decades (Abadan-Unat, 2009,1976; İçduygu and Sert, 2016). As Icduygu and Sert (2016) state, among these emigrants, four-fifths left for Europe and more than two-thirds for Germany. This is the reason why migration from Turkey to Germany has received a lot of attention from policy-makers, researchers, and the public in both countries, as well as in Europe. As Toktas (2012) states, “...emigration to Germany has been the hallmark of contemporary Turkish immigration in contemporary Europe, and it has constituted the backbone of the 'Euro-Turk' phenomenon." I also aim to compare Germany as the well-known destination country for Turkish worker migrants with a lesser-known destination country, the US, but a country that has been the main destination for Turkish qualified migrants.

As Karpat (1985) discusses, although emigration from Ottoman lands started during the 1860s, the number of emigrants was insignificant during those early years. The source of the emigration at the time was Syria and, to a lesser extent, southeastern Anatolia. Kaya (2004) also states that Turkish speaking people started emigrating from Ottoman lands to the US during the last quarter of the $19^{\text {th }}$ century and reached the highest numbers during the first two decades of the $20^{\text {th }}$ century. Especially during the 1950s, professionals like doctors and engineers went to the US for having training. Because of that wave of professional migrants, Turkish migrants had a more educated profile during that period. However, with a third wave of migration after the late 1980s, Turkish migrants to the US started to be composed of a more diverse group, including not only professionals and students

\footnotetext{
${ }^{1}$ For an earlier use of the concept "Euro-Turk", see Kaya and Kentel (2005).
} 
but also semi-skilled and unskilled workers. In an article at The Turkish Times, Akinci ${ }^{2}$ called this profile change the "Germanification of Turkish Americans"3:

The bulk of the Turks who immigrated to the U.S. since the late 1950s and early $60 \mathrm{~s}$ consisted of highly-educated professionals, doctors, engineers, university professors, accountants, finance professionals, managers and students. But for the last twenty years or so I are also witnessing a new influx of a blue-collar group, some of them with no or very little education, and mostly employed in the low-paying service sector. In that sense, these new arrivals resemble more the profile of the Turkish community in Germany in particular, and Europe in general than the white-collar cross-section of the earlier arrivals to the United States (Akinci 2002).

There are also those scholars who criticise the elitist attitude in the comparisons between the Turkish migrant populations in Germany and the US (Thibos, 2014). Recognising the diversity of the migrant populations from Turkey in both Germany and the US, the current study focuses on the group of qualified migrants in both countries.

\section{The study design}

This is a qualitative study which depends on an analysis of semi-structured interviews with 80 returnees, 40 from Germany and 40 from the US (50\% women, $50 \%$ men). The research is about the return of qualified migrants, and as qualified migrants, I focused on those people who emigrated either with an undergraduate degree or as an exchange student from one of the universities in the big cities of Turkey. Additionally, I only chose those who migrated to one of these two countries for further education or professional work experience, who stayed in these countries for at least five years and had at least one year of professional work experience (assistantships are included). I reached those individuals who met all these criteria. I used social media and targeted snowball sampling to reach our respondents.

Additionally, I posted ads in places like Turkish-German Bookstore and Cafe. I interviewed our respondents in their offices, private spaces at universities, cafes and restaurants, and in a few cases, on Skype. I recorded 78 of those interviews ${ }^{4}$ and transcribed them. I read all the interviews several times. I made an analysis for each question separately, as well as analysing together the groups of questions related to the same theme. I also made a comparative analysis of the responses of returnees from Germany and the US.

Among 80 respondents, 40 of them were male, and 40 were female (male: 25 , female: 15 for returnees from Germany; male: 15, female: 25 for returnees from the US). The average age was 46 for the returnees from Germany and 38 for the returnees from the US. Among 40 people who returned from Germany, 18 had PhD's, 12 had master's degrees, and 10 had Bachelor's degrees. Among 40 returnees from the US, 24 had PhD's, 14 had master's degrees, and 2 had Bachelor's degrees. The average period of stay in Germany is 12 years (ranges between 5 and 27 years), and

\footnotetext{
${ }^{2}$ Uğur Akınc1. "Germanification of Turkish-Americans," accessed January 2018, http://gencturkler2.8m.com/ IMMIGRANTS/ turkish_torque.html

${ }^{\overline{3}}$ See also Micallef (2004), Köşer Akçapar (2009).

${ }^{4}$ Two respondents did not give consent for recording of the interviews. We took notes during those interviews.
}

Copyright @ 2020 BORDER CROSSING 


\section{Turkish qualified returnees from Germany and the US}

the average period after return to Turkey is 9 years. The average period of stay in the US was 8.4 years (ranges between 5 and 15 years), and the average period after the return was 4.5 years.

\section{Prior familiarity with the language and culture of the host society}

Language is an important component of one's identity. As the person needs to live his/her life in a different language after migration, this change also has implications for identity. Depending on the familiarity with the host country's language prior to the move, the form and extent of the identity shift may differ. Among our respondents who lived in Germany, there were three groups according to the level of familiarity with the culture and language of Germany when they first went there. The first group included those who went to Germany with advanced knowledge of English, but limited knowledge of German language and culture. This was the largest group in our study. Although they were accepted to programs in English or employed in international companies which used English as their main language, still they experienced difficulties both at work and in daily life because of their limited proficiency in German. They did not have much previous exposure to German culture, either. As I will discuss further, these people mainly interacted with other foreign students and/or professionals who were also speaking English in their daily lives. They mostly adapted to that "third culture" which was created by different groups of foreigners living in Germany. Their cultural strategy was trying to maintain the original culture while also interacting with people from many cultural groups, but not necessarily from the host culture.

The people in the second group were educated in German high schools and/or universities where the medium of instruction was German, had familiarity with German culture and knew German when they migrated there. The last group had family members who have lived in Germany. They had previously been to Germany for varying durations and had varying degrees of competence in language and familiarity with the culture. For both groups, their long-term migration was not their first contact with the host country culture and language; they already have some components of the host country culture as part of their identities when they migrated. However, as I discuss elsewhere, many of them considered discrimination as a major negative aspect of their lives as Turkish people in Germany (Yilmaz Sener, 2019). Many of them believed that regardless of their language skills and knowledge of the culture, they would always be perceived as foreigners and outsiders because of their Turkish ethnic identity. In other words, the context allowed them to have limited interactions with the host culture, and strategies like Assimilation or Integration were not available to them. In the same way as the first group, they mostly interacted with other foreigners.

My German is pretty good. It is in fact my native language. I was born in Germany and came to Turkey when I was nine. I lived here, in Turkey for fourteen years, and then between 1979 and 2000, I was in Germany again. I was familiar with the country's culture. Part of you may be German, but still, you are always a foreigner there. Being familiar with the culture does not change anything. It doesn't change the fact that you are perceived as a foreigner. (52)

In a different way from the ones who lived in Germany, the clear majority of those who lived in the US knew the language of the country, English, at an advanced level when they first migrated. However, compared to their reading and writing skills in English, their speaking skills were at a lower level in many cases. They especially had difficulty speaking English in daily life, not having done it in the past. Many of them had very few international travel experiences before their 
migration to the US. Additionally, speaking English with a foreign accent also brought some difficulties in everyday communications.

When I went to Seattle, I had no problem speaking English. But then I went to Eugene, Oregon. That was a very small city, with a population of one hundred thousand. I had a lot of difficulties there. People were not used to hearing accents, and socially, I had difficulty while I was speaking English. Technically, my English was quite good, and I did well academically. But I had difficulties in social life. (22)

Everyday language is a lot harder. We were always using the academic language, so we were more familiar with it. But in everyday life, if you try to use the same kind of language, then you become funny. They don't understand what we say. After we went to the US, we realised that. What we did to get over that problem was watching TV series, like Friends... Friends helped me a lot to learn what they say in different situations. (41)

Especially the TV series that they regularly watched during their stay in the US seemed to have helped them for learning some cues about the everyday language and culture. Also, the reference to Hollywood films and TV series that I see in the last quotations was in fact something that I frequently came across in our interviews. Their previous contact with spoken English by native speakers, as well as with American culture was mostly through Hollywood films. When I asked them their level of familiarity with American culture before migration, many of our respondents told that what they know about American culture was mostly through Hollywood films. Many of them seemed to compare their lived experience with what they saw in those films. However, they had different ideas about to what extent those two corresponded. For some, they already had known a lot, thanks to those films, and they did not get surprised about many things when they started living there. For others, there was a low level of connection between what is represented in Hollywood films and the "real" American culture.

I think for Turks, there is a lot of familiarity with American culture. All the films that we have been watching... Our culture is influenced so much... So, I did not really feel like a stranger when I first went there. I saw those locations where the films take place, that lifestyle... This is the kind of lifestyle that has been imposed on us since childhood. (40)

If you watch TV, you see some objects, some pictures about America. Let's say, the subway in New York... Even those people who have never been to America can tell you at least something about the subway. Or let's say Chicago... We have all seen things about Chicago in films or TV series... So, I went to America having certain ideas about its culture. Some of them were true; others were not... Or to be more accurate, I can say I learned new things. I wouldn't say, I had this perception about America and it was totally wrong. Not necessarily that... But I mostly saw that it was incomplete, partial. Because there are many dimensions, and we previously did not necessarily know all. But I wouldn't say that it was all incorrect, or I wouldn't say that what we saw on the screen doesn't exist. It's just incomplete... (58)

Familiarity with culture... Only based on American films... When I first went to New York, I felt like I was in a film set. Many films take place in New York, so in my head, 


\section{Turkish qualified returnees from Germany and the US}

the film and reality corresponded. But what didn't coincide was, I was expecting a more luxurious place. It wasn't. There was this Manhattan Mall... Compared to the malls in Istanbul, it was nothing. Very much like the first times of Galleria Mall in Istanbul...

The ones who had their high school education in American high schools in Turkey, or Turkish universities which have ties to the American educational system (Bogazici University, Middle East Technical University, Koc University, Bilkent University, etc.), stated that they had learned some things related to American culture at school. However, in the same way with what they watched in American films, what they learned at school did not necessarily coincide with the "real" American culture. According to them, the kind of culture that is maintained at those American schools is an idealised culture. However, coming from such schools/universities made it easier for them to get adapted to the educational system in the US.

The version of American culture in Turkey is, I think, totally different. We have a very different image of America... When I went there, I discovered a totally different world. I was educated at an American high school here. We were calling our teachers $\mathrm{Mr}$ and Mrs... When I was there, I even called the people who were a lot older than me with their first names... The image of America in American colleges, high schools in Turkey, is more ideal than it really is. (31)

Some of them discussed the aspects of culture and social life in the US that they did not encounter in those films, and that surprised them. All our respondents have urban backgrounds, and most were raised in the biggest cities of Turkey. Many of them were thinking of the US as composed of big cities, and especially those of them who went to smaller places in the US were surprised to see that many people live in small towns, not having urban lifestyles. When they met people from the countryside in the US, they were astonished by the fact that there were many who had never been to the big cities in the US, or they did not know much about the rest of the world. Another thing that they found disturbing about their interactions with the country people was that those people were treating them as non-Westerners, who were coming from an underdeveloped country, and assuming that they had less knowledge about "civilised life". However, coming from urban, middle-class backgrounds, they were thinking that they were interacting with "rural" people who had lower standards in terms of lifestyle.

At the university, when I interacted with the administrative staff, or with the volunteers in English speaking courses, I was astounded. They were unbelievably rural! They had no idea about the world. There were people who had never seen Chicago. This was something that I wasn't expecting. Like the people who had never gone out of their villages in Turkey... Another surprising thing was... We were living in campus housing. All the home appliances, washing machines, dishwashers were so old-fashioned compared to the ones that we use in Turkey... And many Americans were not even aware of that. Those of us who were non-American, we were laughing at it. We were using those machines like fifty years ago! (18)

The orientation programs or international offices gave them some materials or courses which provided ready-made frameworks and suggestions to understand the difference between American culture and their cultures. These materials were based on homogeneous understandings of national cultures, and notions of strict boundaries between different cultures. The ironic thing was, those 
materials were presenting simplistic understandings of culture to people who came for $\mathrm{PhDs}$ in areas like sociology, anthropology, media studies, or communication and had previous exposure to sophisticated discussions on culture. Some of them found the suggestions offensive:

When we first went to university, they gave us a booklet about American culture. I never forget one statement in that booklet. It said, it may be different in your culture, but in America if a woman says 'no', it means no. She can go to the movie theatre with you, but this doesn't mean that she likes you. You know, Americans have this kind of attitude, but I wasn't used to it then. I got angry. What do you mean, like we are ignorant people (dagdan inmis) who wouldn't know that it means 'no' when somebody says 'no'... (18)

There were those who told that they had negative attitudes toward American culture before living there. Especially those who have left-wing political inclinations were critical of the US, and its culture. Although their ideas have changed after their stay, that change was not necessarily toward a positive direction.

I did not have much familiarity with American culture. I was pretty negative about it. To the contrary, I had ideas like they intervene in other countries' affairs, they ruin everything, they are irresponsible... So, I had a hostile attitude. But I was also thinking that they have the power, so I should go there... Before going to America, I was thinking that American people knew about everything, but they gave consent to what was going on. But after living there, I saw that it is not the case. American people are, in fact, ignorant, and they have no idea about what is happening. You can see it if you watch the news. They really believe that America is trying to help other countries. (74)

If I summarise the discussions here, I can say that most of the people who migrated to the US had previous contacts with the language and culture of the country. Mostly being proficient in using academic English, they had to gain new skills to start using English in their everyday lives. Although their previous knowledge about American culture gave some ideas about the "real" American culture, it had to be revised in line with what they directly experienced after living there. However, because of the impact of American media and Hollywood films, the migrants did not feel like it was their first contact with a different culture.

\section{Their social groups in Germany/the US}

I asked our respondents whether their social circles were made up of other Turkish migrants, Turkish-descent second-generation people, the other citizens of the host country, or other foreigners while they were living in Germany/the US. During our interviews with the group of returnees from Germany, what I heard frequently was their initial intention to "stay away" from other Turks, and to socialise with German people so that they would be integrated to the host society. They had the intention to avoid Separation, a situation in which they would stick to their original culture and avoid interactions with people from other cultures. However, for most of them, this intention could not be realised.

When I first went to Germany, I did not want to hang out with other Turks. I went there to learn about the culture and to meet German people. That was the aim... In the beginning, it was hard to find an apartment in Hamburg. As a foreigner, as a student... In Hamburg, many don't rent their apartments to foreigners. But the university had these accommodations for students. The International Office introduced me to a friend from 


\section{Turkish qualified returnees from Germany and the US}

Turkey. They said you can stay together. And then, I started meeting people who came from Turkey. ...While I was aiming to make German friends, I ended up in the Turkish community. (1)

For the majority, their social circle was mostly composed of other foreigners and educated Turkish people like themselves, who migrated for further education or professional jobs. They were considering permanently-settled and second-generation people with Turkish roots as having a totally different culture. Although some of them had relatives or family members who had previously settled in Germany, some of them were trying to keep themselves out of those social groups, which they considered as lower-status. The ones who had no previous familial connections with Germany also had limited contacts with the settled Turkish community there. Social class, educational differences, and cultural difference played a major role in these distinctions. They wanted to distinguish themselves from Turkish guest workers. However, there were also some of them who were critical of these class distinctions.

I mostly had relationships with the citizens of other countries. We were all coming from different countries, and we had that in common. I had a problem when I was spending time with people who came from Turkey. Because those of them who were highly educated looked down on Turkish labour migrants. Because of that, I hated being with them. (61)

Those of them who had education at universities where there were a lot of international students or worked at international companies where the working language was English told that their social circles were mostly composed of other foreigners. The fact that they were all living in a country other than their home country, struggling with similar problems, and using English for communication led them to be in more frequent and better communications with the other foreigners.

During the first period, we especially socialised with the expat community, the other expats in the same company. My wife had some friends from the language course. We were also meeting them. Later, we also had a couple of Turkish friends. Our group was totally international. There were American, Swedish, Polish, Spanish, French, and English people. There weren't really many Germans... (5)

My social circle was mostly composed of international students. Both in the master's program and at the student housing... Mostly with international students from Bolivia, China, Jordan... I didn't have many Turkish friends. There was only one girl that I interacted with. (57)

Only four respondents mentioned having German, as well as international and Turkish friends. In a group of forty people, this is obviously a very low ratio, and it gives an idea about the low level of contact between these migrants and German citizens. Even those of them who mentioned having interactions with Germans talked about superficial relations and merely socialising, rather than having deep and close connections. Not having been able to establish deeper connections was something that many of them complained about. Therefore, there was a very low level of interaction with people from the mainstream culture of the host society.

Considering the returnees from the US, we saw a similar situation with the returnees from Germany in terms of their social circles in the host country. They were also mostly in interaction 
with the other foreigners and, although at a lower level, with recent Turkish migrants in the US. However, especially students described more international environments compared to those who lived in Germany; some of the graduate programs had more international students than American students. Therefore, adaptation to the "third culture" applies even more to the American context. There were fewer interactions with the minority Americans and the second-generation Turkishdescent people. However, the most limited was their relations with white Americans. As I discussed elsewhere, most of the returnees from the US were thinking that they were not exposed to negative discrimination in the US. However, they did not have many opportunities to interact with individuals from the mainstream culture, either.

I had friends from minority groups, like Mexican-American or Greek-American. Or other international people, of course... (18)

There were many international people around us. My spouse was having a $\mathrm{PhD}$. We were living in an apartment complex where at least eighty per cent of the people were foreigners. So yes, we most frequently interacted with other foreigners. (14)

Mostly with the citizens of other countries... I was in an international group where all were students who went to the US to study. One of my closest friends was Indian, another was from Iran but had stayed in Turkey for specialisation. We weren't really in close relationships with Americans. Because we were trying to adapt, and we had a chance to socialise with people who were like us and who had similar problems with us. We could understand each other... (53)

Similar to the German case, some of them went to the US thinking that they should "stay away" from other Turks to improve their English and to get adapted to the US. Hence, they also aimed to avoid Separation. Nevertheless, that decision had, in most cases, been revised after going to the US, and many had been in close relationships with the other Turkish migrants. According to their accounts, Turkish migrants living in the US varied according to many dimensions, like being single or married, having kids or not, being students or professionals, being religious or not, political inclination, etc., and people were choosing the ones who were most similar to them for friendship. In those cases where the other Turks were significantly dissimilar from them, they chose not to interact with those people. Therefore, contrary to the general tendency to consider migrants from the same country as a homogeneous group, I see that there are all kinds of variations within those groups, and migrants from the same home country do not necessarily prefer to interact with each other in the host country context.

\section{Membership in Turkish Associations}

For both groups of returnees, the level of membership in associations was low before their migration to Germany/the US ( 4 out of 40 for both groups). Membership levels increased to a large extent after migration. 21 (out of 40) respondents reported that they had membership in an association in Germany, and 20 (out of 40) reported having membership in the US. Through these memberships, they aimed to strengthen their professional connections, get support and practical information, defend their rights as foreigners/migrants/Turks, and finally, inform Germans/Americans and other foreigners about Turkey. Many of them became members of scientific and professional associations and Turkish (especially student) associations in Germany/ 


\section{Turkish qualified returnees from Germany and the US}

the US. However, the opinions about and attitude toward Turkish associations varied. Some of them had important positions in these associations or helped to establish them.

I was on the board of the Turkish student association at the university for two years; I also had a role in its establishment. I remained a member until I returned to Turkey. That was my only membership. I was actively involved in the organisation of social activities. Our mission was informing people about Turkey and Turkish culture... Besides that, we were also organising some get-togethers... (39)

An association was established, and they made me the head of that association. Especially for lobbying... I was the head of that association until I returned. We were active. Education, concerts, theatre, Turkish music, seminars... We also had a program on TV. There was that TRT-Int Channel. We had a program on that channel... (79)

We had an association named Sinematurk. We still talk about it with pride... That was our most successful activity. We were organising Turkish film screenings. We were also bringing actors and directors from Turkey. (80)

There was this association of ours, Türkische Theatre Gruppe, that was my only membership. I did not become a member of political or other associations. (65)

I was the vice-president of a Turkish association there. We established it at SUNY. We were showing Turkish films, we had Turkish nights on important days. We had folk dances. We had concerts. I love singing folk songs. I sang, and a friend played baglama ${ }^{5}$. So, we were organising such activities. (74)

Others became members of Turkish associations for socialising, getting support, and practical information. It seems that these organisations have been most successful in providing practical support and know-how.

In every city I lived, I searched for those associations. Because I could always get a lot of practical information from them. Information related to visas, passports, Turkish groceries... I was always in contact for that kind of information. I wasn't regularly attending all their activities, but I wasn't disconnected, either. (19)

Some families who were raising kids in Germany/the US found the activities of Turkish associations useful, as their kids could have some access to Turkish history and culture through them. Secular Turkish families found it important that their kids could learn about Ataturk, and important national days, like April 23rd, National Sovereignty and Children's Day, October 29th, the Republic Day, or May 19th, Commemoration of Ataturk, Youth, and Sports Day:

The activities of our organisation contributed a lot to the Turkish community. For the festivals on April $23^{\text {rd }}$, we had showings of Karagoz and Hacivat ${ }^{6}$. We had these shows in both English and Turkish. I, myself, wrote a script of a puppet show, which also had Karagoz in it. Karagoz explains to Mini Mouse the importance of April $23^{\text {rd }}$. It is like

\footnotetext{
${ }^{5}$ A Turkish string music instrument.

${ }^{6}$ Traditional Turkish shadow play which was popularized during the period of the Ottoman Empire. Karagoz and Hacivat are the main characters of this play.
} 
they came to my house without my permission, they took my toys, but then Ataturk came $^{7}$... So, pedagogically, I wrote it in a way that the kids would understand. (24)

We had activities on Republic Day, May $19^{\text {th }}$, April 23rd... A Turkish School was established. At the time, I did not have a kid. But families with kids wanted to have a Turkish school to teach their kids about Ataturk, about Turkey... The kids did not know anything. I had a friend. His kid thought it was George Washington when they showed the picture of Ataturk. They were in such a bad situation. (69)

According to some, constant and frequent contacts with the people in Turkish groups led to more seclusion and fewer interactions with the host society. Their will to spend time with other Turkish people was based on a psychological need; they found it comforting. But it also had negative consequences in terms of adaptation. Therefore, they felt that membership to these associations led to Separation:

It also had its disadvantages. When we got exhausted in our relationships with Germans, we found comfort in these groups. But then we started to spend most of our time with them, to feel good about ourselves. (63)

During my first two years in the US, I spent a lot of time with Turks. But then I decided to stay away from Turkish groups. They are closed communities. It made my adaptation to the $\mathrm{PhD}$ program more difficult. I was with them all the time. I was unable to get adapted to the country, to the culture, could not improve my English... In the end, my advisor said, you are spending too much time with them. You should be in the department more. We were like living in Turkey while in fact living in the US. After that, I started to limit my interactions. I was only meeting a couple of people, rather than attending group activities. (19)

There were those who preferred to participate in some activities of these associations without becoming members. They were in favour of Integration; they wanted to have a connection to the home country culture but did not want to be totally occupied by the issues and conflicts of the home country. The political inclinations of those associations or of the existing members was a major reason why they did not want to become members. Differences in political positions also caused some to leave these associations. Political and ethnic conflicts in Turkey were transferred to the host-country context:

There was this Turkish student association which was established in 1978. I was a member of it. It was in the hands of a group supporting the ideas of Mihri Belli ${ }^{8}$. But later, it has slowly become dominated by nationalists. We were also members, but we were all social democrats. I tried to organise them and had meetings with them. But when we went to the general assembly, they attempted to beat us. And then, I said, this is over. (76)

\footnotetext{
${ }^{7}$ This is how she explains the War of Independence and establishment of the Turkish Republic.

${ }^{8}$ A leader of the socialist movement in Turkey, who was prisoned and forced into exile for his political views. 


\section{Turkish qualified returnees from Germany and the US}

Finally, some of them wanted to totally stay away from Turkish associations and groups as they found them nationalist and isolationist. They thought that kind of isolationism would make it harder for them to establish a new life in the host country.

I never felt like I belonged to those groups. They are isolationist and nationalist. I could not identify with them. I stayed away from them. (54)

The Turkish association there... What did not appeal to me was that they put too much emphasis on protecting the Turkish culture, and not embracing the American culture. That wasn't good for me at the time. I wanted to see and learn new things. (9)

I wasn't a member of the Turkish Student Association (TSA). I think their activities were too nationalistic. When we first arrived on campus, some friends from the TSA picked us up and helped us a lot during the initial stages. However, in many of their activities, they had this patriotic stance. (18)

In general, I stayed away from the other Turks. You know, when you live there, it doesn't make sense to have those migrant conversations (gurbetci muhabbeti). I did not really need it... (20)

There were a few people in the group of returnees from Germany who mentioned membership in mosque associations. The following respondent talked about establishing connections with the Turkish community through the mosque associations and benefiting from these connections economically.

The Turkish community in Germany has been organised around mosque associations...I have that kind of personality, I had contacts with all of them. The mosque of National Outlook $^{9}$, the mosque of Bosnians or Arabs... We made contacts through them and did business with those ethnic groups. We acted as their social consultants. We were both connected to that community economically, and also made contributions to them. (47)

Among the group who lived in Germany, there were also those who became members of associations related to immigrants or refugees, and human rights associations. Living in Germany as migrants, they seem to have become more interested in issues related to human rights and migrant rights. Some of them have also struggled actively against discrimination and xenophobia. As mentioned previously, there has been a significant increase in their association membership after migration. Some of them were also increasingly politicised during their stay in Germany.

First, I went to the Ataturkist Thought Association ${ }^{10}$ there. They immediately appointed me to the board... I had executed a campaign then. At the time, Germany attempted to waive the visas of teachers coming from Turkey. We organised a petition against it. It was successful, and they stopped the practice. We were also indirectly connected with the consulate. We were presenting our ideas to the consulate, to the education representative. We had also established a youth association. We went to Warsaw to

\footnotetext{
${ }^{9}$ National Outlook is a religious-political movement in Turkey, which has also become one of the leading Turkish diaspora organizations in Europe.

${ }^{10}$ A secular organization which advocates the ideas of Mustafa Kemal Ataturk, the founder of the Turkish Republic. The association is opposed to Islamist ideologies.
} 
attend a convention of human rights associations. At that convention, we expressed our criticisms and complaints about xenophobia in Germany. (45)

I became politically very active in Germany. When I was in Turkey, in Istanbul, I was definitely not active in the political sense. But that community there (in Germany) drew me in... (75)

\section{Frequency of visits to Turkey}

Among the group who returned from Germany, 33 of them told that they visited Turkey at least once a year, in many cases twice-a-year or even every two months, during their stay in Germany. Their family members also frequently visited them, although not with the same frequency. Therefore, especially due to the physical proximity and relatively lower costs of travel, migrants in Germany were in frequent contact with Turkey. This was one of the major differences between the two groups: Those who lived in the US could visit Turkey much less frequently; more than a quarter of them could visit Turkey less frequently than once-a-year. Additionally, many of them were never visited by family members. Long distance between Turkey and the US, and hence, long and expensive flights made it impossible for many of them to visit Turkey frequently. Several respondents described having felt very bad when they could not visit Turkey due to financial reasons.

I visited Turkey at the end of the first year. But then, I could not come for three years. Because of financial reasons, I could not come. After that, I came every year. During those three years, not being able to come to Turkey had such a terrible impact on me! After that, I did whatever it took to come to Turkey every year. (8)

As I will discuss later, less frequent contact with Turkey made them more detached from the cultural changes in Turkey and made their re-adaptation to Turkey difficult after their return. There were cases in which the person could not visit Turkey for very long periods of time because of concerns about the visa status:

During the first five years, I could not come to Turkey. After five years, when I came, everything had changed... At the end of the second year, I was trying to change my visa status, and they told me not to go to Turkey. There was $9 / 11$, and they said, you are Muslim; you may not be able to get a new visa if you go back to Turkey. Because of that, I stayed in the US during the entire process. The process took a long time... Therefore, I could not come here for five years. Even if I wanted to, I couldn't... (10)

I rarely visited Turkey. I stayed in the US for almost fifteen years, and I came to Turkey only three times... I had this Green Card problem. I was renewing it, but each time, I was getting a special permission from the Immigration Office. If I had left the US, I could have been unable to return. I did not want to take the risk. So, I only came three times. (20)

\section{Following the social and political developments in Turkey}

The vast majority of the respondents ( 35 out of 40 ) who previously lived in Germany talked about regularly and frequently following the news about social and political developments in Turkey. Those who migrated to Germany during earlier periods mostly mentioned reading Turkish newspapers and following Turkish TV and radio channels. During especially the last decade, the 


\section{Turkish qualified returnees from Germany and the US}

internet and especially social media became the main channels for following the developments. There were even those who told that they were following the developments in Turkey on an hourly basis from the internet and became more involved in Turkish politics after leaving Turkey. They also mentioned having discussed the political events within the Turkish groups, and on the phone with their family members and friends. Many of them also mentioned having followed the political developments in Turkey much more frequently during their time in Germany, compared to the period after their return. Therefore, it was of high importance for most of them to be aware of the political and social developments in the home country, when they were away.

During the period when I was in Germany, I followed the news almost on an hourly basis. That frequently... From the internet, reading the newspapers, and also checking eksisozluk ${ }^{11} \ldots$ (21)

I was following the news much more frequently than I am doing now. I was reading the newspapers from the internet every day. I had long phone conversations with my parents, and I was learning a lot from them. Each time I came to Turkey, I was staying for at least two weeks, and in my conversations with friends, they were updating me about the recent developments. I was closely following what was going on in Turkey.

Another respondent who was active in movements related to Turkish politics while he was living in Germany stated that he did not only follow the political developments but "lived within them". However, their oppositional activism had consequences for them, even while living in a different country. Turkish authorities were keeping track of the activities of Turkish citizens on foreign soil through the consulates:

We were very organised in Germany. We were organising protests against the military coup on September $12^{\text {th }}$ and the military dictatorship. Both in Germany and also in other countries of Europe... We went to Brussels, for instance, and in front of the European Parliament, we protested human rights violations and the conditions of prisons in Turkey. And then, the consulates found out our identities and cancelled our passports. Some people lost their citizenships. (75)

There were only four people who told that they did not regularly follow the news about Turkey. Not having enough time and energy to be up-to-date with the events in both Germany and Turkey, giving priority to learning the current events in the German context rather than the Turkish one especially for being adapted to the host country, and trying to protect oneself from especially the psychological impact of the political developments in Turkey were their major reasons for not closely following those developments. Therefore, this small group of people were the ones who believed that their new life in the migrated country required them to be more focused on the social and political life in that country, rather than their home country. They were closer to an Assimilationist stance in that respect. As I will discuss later, re-adaptation after the return has been harder for this group, which is in line with the findings of Sussman (2000).

Compared to the returnees from Germany, fewer returnees from the US mentioned regularly following the news about Turkey while they were living in the host country. Those of them who

\footnotetext{
${ }^{11}$ Eksisozluk is a collaborative online dictionary built with the contributions of the users. The content in in Turkish. 
went to the US during earlier periods talked about the difficulty of getting frequent information about the events in Turkey then. For those who migrated after the 2000s, the internet made it possible to follow the news daily. Although fewer people mentioned regularly following the news about Turkey compared to the returnees from Germany, still many of them daily read the Turkish newspapers from the internet or kept track of the current events through social media channels, like Facebook.

Always... The first thing that we were doing in the morning was checking what happened in Turkey. We were following everything very closely. Both my wife and I... That was also what I saw in all the Turks there... Form the internet, reading the newspapers... (66)

I was following everything as much as I could. Especially after the elections, I was following even more closely. I certainly wanted to know what was going on in the country. I was reading the newspapers on the internet. (74)

In addition to following the news, some of them also talked about watching soccer matches and following the Turkish TV series from the internet regularly. In addition to watching them on their own, there were also those who were watching them together with other Turkish people. Most of them did not have any Turkish channels. They believed that it would be better for their adaptation if they watched American channels. However, they were still watching those series from the internet right after they were broadcasted in Turkey. This made it possible for them to keep in touch with cultural life in Turkey.

I did not have a Turkish channel, but I was regularly watching the soccer matches from the internet. I was also regularly watching some of the TV series. Ezel ${ }^{12}$ was very popular at the time. We had those Ezel nights. On Mondays, we had our master's class until $6 \mathrm{pm}$, America time. So, it was being broadcasted and uploaded by then. We were coming together with the other Turkish friends and watching Ezel on Mondays. (43)

I was following the TV series. From the internet, I was watching many TV series... Like Ask-i Memnu ${ }^{13} \ldots$ I was following them, and also the political developments at the same level as I do when I am in Turkey... (25)

Ten people (out of 40) stated that they did not follow the news about Turkey frequently. These people tried to become informed when there were important events, but otherwise, they did not made the effort to follow the news every day. They thought that it would have negative consequences in terms of adaptation if they tried to keep track of every event in Turkey. As adaptation took time and effort, they did not want to spend their time getting constant updates about Turkey. For this group, keeping track of the cultural and social life in the home country was more important.

I did not really follow everything closely or frequently. Occasionally, I was reading the news from the internet. I had somewhat isolated myself from the political developments

\footnotetext{
${ }^{12}$ Ezel is a famous TV series which was broadcasted during 2009 and 2010, and gained a considerable fan base in Turkey.

${ }^{13}$ Ask-1 Memnu means forbidden love. It is a Turkish TV series broadcasted between 2008 and 2010. It was adapted from the 1899 novel of Halit Ziya Usakligil, which had the same name.
} 
in Turkey. When there were big events, I was getting information about them from the internet. But otherwise, I wasn't tracking everything... (9)

Not very often... Just once in a while... I was spending all my time to get adapted to the new environment and to improve myself in my profession. I was sometimes checking the news for distracting myself. But, at the time, my focus was not on what was going on in Turkey. The focus was on gaining a place in the new country. (53)

The longer they lived in the US, the more detached they seem to have become from the political and social developments in Turkey. Even when they wanted to keep track of those developments, they could not do it after long periods of time passed in the host country.

It is not easy to follow the developments in the two countries. I was living there, and I felt the need to learn about sports events, pop culture, health, etc. in the US. Therefore, I could not really follow everything about Turkey. I knew about major events. But except those, I wasn't following much. I was a little bit disconnected. So, now, I sometimes feel like a stranger in Turkey. (10)

Therefore, as I will discuss further, the ones who were more oriented towards the culture of the host country had a harder time re-adapting to the home country culture after the return. This is also in line with the arguments of Sussman. However, after deciding to return, some of them spent more effort to be updated about the political and social events in Turkey, to make their re-adaptation easier. These individuals were aware of the difficulties they would experience after return:

During the first period, I wasn't regularly following the news about Turkey. But as my return to Turkey approached, I started following everything... Both about the political and economic developments... To understand where I am going, what I am doing... (22)

\section{Reasons behind the decision to return}

In response to the question about return, many of our respondents told that for many Turkish migrants living in Germany/the US, returning to Turkey is a subject that they constantly discuss with other Turkish people.

I was always thinking about returning to Turkey. This was something that the people there were discussing all the times. To return or to stay... (42)

For the returnees from both countries, their longing for the culture of the home country (as well as the longing for their families and friends) was a major reason behind their return.

The reason was longing... We had a comfortable life there. We were making a lot of money... But at the end of the day, money is not everything... The most important factor for us was longing. Longing for friends, family, culture, and life in Turkey... (Senior Design Manager)

First, my family is here. My mother, father, siblings... Second, we love our country. With its positive and negative sides, we love our country, our home. I used to miss Turkey a lot." (Engineer)

As I discuss elsewhere, for the returnees from Germany, being exposed to discrimination in the host country, and never feeling belonging were also important reasons behind their return. 
If I had been comfortable living in Germany, if I had been accepted as I am accepted here, I would not have returned to Turkey. Because they always make you feel that you belong here, not to Germany. You may get something that you deserve by working hard. But still, they make you feel that they give it to you, you don't really deserve it. In daily life conversations, in jokes, they always emphasise that you are a foreigner. (Officer at an NGO)

I was never comfortable there in the psychological sense. I was always repressed because of my own identity. I never felt that I belonged, and I never felt happy while living there. So, I always wanted to return even if that would mean earning less. (Associate Professor)

For the returnees from the US, discrimination was not necessarily something that characterised their experience in the host country. However, many of them still believed that it wasn't possible for them to feel belonging in the US. They thought about Turkey as the place where they belonged to.

There were many reasons for our return. But the major one was belonging. In Turkey, being able to speak your own language... That's a wonderful thing for me... I always felt that I belonged here. I was thinking that I don't know when, but at some point, I should go back to Turkey. (29)

The feeling that they belong to Turkey, in some cases, also came together with the feeling that they owe a debt to their country. They were feeling guilty because of leaving Turkey behind, and they were feeling that they had the responsibility to return and help to bring some improvements in the country:

I guess there was that feeling of responsibility and guilt. Because of being born and raised here... I was feeling like I was leaving something bad behind, and finding everything ready there. But I hadn't contributed to the state of things in the other country. I was thinking that I owed it to this country to come back and struggle here. (13)

As people who felt their main attachment and belonging to Turkey, some of them also wanted their kids to belong to Turkey, to be socialised in the same culture with them, and not to "become American". They decided to return when their kids were still young enough to accept Turkey as their home and to grow up becoming like their parents.

We always had the idea of returning to our country. We wanted our daughter to grow up in the same environment with us, to grow up in her culture... We wanted her to be like us. That was the major factor behind our return. (74)

While they were willing to return mainly to feel belonging, the idea of return was also frightening, especially for those of them who migrated at earlier ages and stayed in the host country for long years. In the following case, the person first tried to live in Turkey for a period of four months, but then went back to the US. A couple of years later, she went through a process of therapy, and after that, she felt ready for her return to Turkey:

When I returned to Turkey, I was thirty-one. All the people around me were returning, and I had also started considering it. When I was twenty-eight, I put all my belongings in a depot in Chicago and came to Turkey for four months to try living here. But then, I 


\section{Turkish qualified returnees from Germany and the US}

went back to Chicago and carried on with my life there. I was afraid of returning to Turkey. I was feeling more like American. My friends here were saying, wow, you became Americanized, your Turkish became different. I was afraid that I wouldn't be able to adapt to social groups and relationships here... I thought about it for a long time. I also got support from a therapist before my return. I wasn't sure whether I was making the right decision. It was an important change. (10)

\section{Re-adaptation to the home country culture after the return}

For these migrants who returned to Turkey from Germany and the US especially for reasons related to culture, what makes them happy about their current life in Turkey is also related to culture. They talked about feeling more content living in the country where they belong to, speaking their native language, having closer and deeper relationships with people, and being close to their loved ones as the most positive aspects of their current life.

There is this feeling of belonging. It makes me feel comfortable. Even if I don't approve of the behaviours of many people, I know that I belong here. That feeling of ease... In the evening, going to the bakkal (local grocery store) in the corner, buying my beer, having a friendly conversation with the baker in the morning. You cannot have them in the US. Here, even on an ordinary street, there are many people who are passing by. You don't have that in the US. There is a lively social life here. Streets are empty there... (42)

We may dislike, criticise, or get angry with some of the things here. But at the end of the day, this country is ours. There is no other... There (in Germany), when you express your opinion, they will always ask, who is this person anyway... In their culture, they don't have a notion of accepting foreigners. (76)

However, despite their happiness about their personal lives and being in their own culture, the general situation of the country is a source of discomfort and concern for most of them. They are worried about the political developments, and the direction that the country is heading towards. Moreover, they complained about many structural issues like the systems that don't function, constant violation of rules and laws, long work hours, traffic, and daily life being a constant struggle. Even those of them who are happy about their decision to return talked about a very difficult process of re-adaptation to Turkey and mentioned experiencing a culture shock after the return. Interestingly, many of them stated that the reverse culture shock that they had in Turkey was a lot harder compared to the culture shock they initially experienced in the host country. During the time they spent in the host country, they have changed, and Turkey has also changed. As a result, it hasn't been easy for them to adjust to the changing context of Turkey after their return.

After living in a country for nine years, your entire life is shaped according to that place. You have your social groups and everything there. You forget about here, and you don't have much left. Things also change here. It is not the same place any more when you come back. Therefore, returning is not easy. When I first returned, it was a traumatic experience. I missed my life there. Like how I missed Turkey when I first went there... 
I am happy to be here now. But when I first returned, I had a culture shock. It wasn't easy to get readapted... In the beginning, I had a huge disappointment. Now, I am learning to take it easy. My initial disappointment has been moderated. (29)

Even those of them who are mostly happy about being back in Turkey miss many aspects of their previous lives in the host country. As the period of stay in the host country got longer, it became more difficult for the returnees to re-adapt to Turkey. However, compared to the returnees from the US, the returnees from Germany had an easier time readapting to Turkey. As I discussed before, frequent contact with Turkey during the period of migration helped them to keep track of the changes in the country better. To the contrary, returnees from the US talked about much longer and tougher periods of re-adaptation, as they were more detached from the context of Turkey during their period of migration. Additionally, I can also argue that discrimination experiences in Germany led those who lived there to feel more comfortable upon their return to Turkey, making the readaptation process easier. Another factor that made the re-adaptation process smoother was a longterm intention to return. When the idea of return was always present, the person's main orientation was towards staying in tune with the culture of the home country, rather than adapting to the host country. There wasn't much effort to develop a sense of belonging in the host country. Although this kind of orientation had negative consequences in terms of adaptation to the host country, it has been helpful upon return.

It did not take long to get readapted. Like an hour (laughs)... At the background, there was always the idea of returning when we were in Germany. And for me, there was never a feeling of belonging in Germany. (Senior design engineer)

Those of them who were more pessimistic about the current situation of Turkey and who thought that many things were going wrong in the country stated that they could not and don't want to adapt to its current state:

I don't think that I could readapt. Maybe it will never happen... I may pretend so if I need to when I am with some people. But in its current situation, Turkey does not look like a country that I can adapt to. (Marketing manager)

Finally, there are a few people within both groups of returnees who think that after their experiences of migration and return, they can now live in any place, any country. This approach may remind us what Sussman calls an intercultural/global identity shift, where the returnees define themselves as world citizens and can interact successfully in many different cultural contexts. However, rather than describing it as a positive experience, those individuals talked about it as a loss: the loss of "home", loss of belonging. They were feeling like they can "survive" in any context due to the capabilities they acquired after migration and return. However, they weren't feeling "at home" anywhere.

\section{Relationships with other returnees and host country nationals after the return}

For both groups of returnees, there is very limited interest in being members of associations for returnees from the same country. Even those of them who were members of such groups described them as inactive groups which were mostly social media platforms. Although many of them mentioned socialising with some returnees, those returnees are the people that they had met during their time in the host country. Also, for the academics, there are many other returneeacademics at their universities and they have ongoing connections with them because of working at 


\section{Turkish qualified returnees from Germany and the US}

the same place. However, most of them told that they don't spend a special effort to meet other returnees. And there were even those who complained about their interactions with their returnee friends; being in groups where everybody was critical of the conditions in Turkey had a negative impact on the re-adaptation process.

Moreover, there is a very low level of interaction with the nationals of the host country living in Turkey. Therefore, it seems that for the majority, there was no additive identity shift; they do not seek out opportunities to interact with members of the host culture. Subtractive identity shift was experienced much more widely, where the returnees feel less content with the home country's culture and don't feel similar to their fellow citizens.

\section{Discussion and conclusion}

In this article, I looked at the identity changes and adaptation processes after migration and return for two groups of qualified Turkish migrants who previously lived in Germany and the US. I observed that for many returnees from both groups, although their previous knowledge about the host society culture had to be revised after their stay in the country, for many of them, it is not possible to consider their time of migration as their first contact with the culture of the host country. During the time of their first migration, many of them had an intention to avoid Separation; they aimed to maintain the original culture while also interacting with people from the host country. However, as Berry (1997) argues, Integration can only be valid for societies that are explicitly multicultural. Due to experiences of ethnic discrimination, for the majority of those who lived in Germany, Integration was not an available option. However, rather than going for Separation by sticking to their own culture, they rather stayed in contact with the other foreigners, being part of a third culture. Although the ones who lived in the US did not talk about discrimination as characteristic of their life in the host country, Integration to the mainstream culture seemed less common in that case, too. With more opportunities to socialise with other foreigners, they participated even more in the third cultural sphere. This shows that even in the absence of ethnic discrimination, foreigners may still be in more contact with the other foreigners, rather than the nationals of the host country.

Frequent contact with Turkey and regularly following the developments in the country applied more to the ones who lived in Germany. Because of physical proximity and low costs of travel, they could travel to Turkey frequently during their stay in Germany. They were not only following the developments in Turkey, but some of them were also involved in activism related to the political developments in Turkey. To the contrary, for the ones who lived in the US, there was less frequent contact with Turkey due to the long distance and high costs of travel. There were more of them who did not frequently follow the developments in Turkey. The longer they stayed in the US, the more detached they became from the political and social developments in Turkey. An extended period of stay in the host country meant a more difficult re-adaptation process to the home country. Also, the ones who were more oriented towards the culture of the host country had a harder time re-adapting to the home country culture after return, which is another finding that supports the arguments of Sussman.

Compared to the returnees from the US, the returnees from Germany generally had an easier time readapting. In addition to the positive impact of more frequent contact with Turkey during migration, discrimination experiences in Germany led those who lived there to feel more comfortable upon their return to Turkey. This also made their re-adaptation process easier. A long- 
term intention to return also made re-adaptation smoother. Although home-country orientation had negative consequences in terms of adaptation to the host country, it seems to be useful upon return.

Consequently, an affirmative identity shift was more prevalent among the returnees from Germany, those who stayed in the host country for shorter periods, and those who had a long-term intention to return to Turkey. For most of the other returnees from both countries, a subtractive identity shift was more relevant. Although most of them returned willingly, they are not content with the current culture and conditions of the home country. This is both because they have changed, and also the country had changed significantly when they were away. Lastly, there were a few of them who stated that after their migration and return experiences, they could live in any culture, reminiscent of Sussman's category of intercultural shift. However, rather than becoming "world citizens" and feeling "at home" everywhere, they described it as a process of loss where they lost their sense of belonging to any place.

\section{References}

Abadan-Unat, N. (1964). Batı Almanya'daki Türk işçileri ve sorunları. Ankara: DPT.

Abadan-Unat, N. (1976). Turkish migration to Europe, 1960-1977. In: N. Abadan-Unat (ed.), Turkish workers in Europe, 1960-1975 (pp.1-44). Leiden: E.J. Brill.

Abadan-Unat, N. (2011). Turks in Europe: From guest worker to transnational citizen. New York: Berghahn Books.

Adler, N. (1981). Re-entry: Managing cross-cultural transitions. Group and Organizational Studies, 6(3), 341356. https://doi.org/10.1177/105960118100600310

Akçapar, Ş. K. (2009). Turkish highly skilled migration to the United States: New findings and policy recommendations. In: İçduygu, A. and Kirişci, K. (eds), Land of diverse migrations, challenges of emigration and immigration in Turkey. İstanbul: İstanbul Bilgi University Press.

Akgündüz, A. (1993). Labor migration from Turkey to Western Europe, 1960-1974. Capital and Class, 17(3), 153-194. https://doi.org/10.1177/030981689305100107

Allison, P. Davis-Berman, J. and Berman, D. (2012). Changes in latitude, changes in attitude: Analysis of the effects of reverse culture shock: A Study of students returning from youth expeditions." Leisure Studies, 31, 487-503.

https://doi.org/10.1080/02614367.2011.619011

Baruch, Y. and Altman, Y. (2002) Expatriation and repatriation in MNCs: A Taxonomy”, Human Resource Management, 41(2), 239-59. https://doi.org/10.1002/hrm.10034

Baruch, Y., Steele, D.J. and Quantrill, G.A. (2002). Management of expatriation and repatriation for novice global player.” International Journal of Manpower, 23(7), 659-71.

https://doi.org/10.1108/01437720210450824

Berry, J. Poortinga, Y., Segall, M. and Dasen, P. (1992). Cross-cultural psychology: Research and applications. New York: Cambridge University Press.

Berry, J. (1980). Social and cultural change. In H. Tiandris and R. Brislin (eds.), Handbook of cross-cultural psychology (pp. 211-280). Boston: Allyn \& Bacon.

Berry, J. (1997). Immigration, Acculturation and Adaptation. Applied Psychology, 46, 5-68.

https://doi.org/10.1111/j.1464-0597.1997.tb01087.x

Berry, J. (2001). A Psychology of Immigration. Journal of Social Issues, 57(3), 615-631.

https://doi.org/10.1111/0022-4537.00231

Berry, J. (2005). Acculturation: Living Successfully in Two Cultures. International Journal of Intercultural Relations, 29, 697-712. https://doi.org/10.1016/j.ijintrel.2005.07.013

Black, S., Gregersen, H., and Mendenhall, M. (1992). Global Assignments. San Francisco, CA: Jossey-Bass. 


\section{Turkish qualified returnees from Germany and the US}

Bossard, A. and Peterson, R. (2005). The Repatriate Experience as Seen by American Expatriates. Journal of World Business, 40(1), 9-28. https://doi.org/10.1016/j.jwb.2004.10.002

Cassarino, J.P. (2004). Theorizing return migration: The conceptual approach to return migrants revisited." International Journal on Multicultural Societie,s 6, 253-79.

Cerase, F.. (1974). Expectations and reality: A case study of return migration from the United States to Southern Italy." International Migration Review, 8 (2), 245- 62.

https://doi.org/10.1177/019791837400800210

Chamove, A. and Soeterik, S. (2006). Grief in returning sojourners. Journal of Social Sciences, 13 (3), 215 220.

https://doi.org/10.1080/09718923.2006.11892552

Cockburn, L. (2002). Children and young people living in changing worlds. School Psychology International, 23 (4), 475-485. https://doi.org/10.1177/0143034302234008

Dewaele, J.M. and van Oudenhoven, J.P. (2009). The Effect of multilingualism/ multiculturalism on personality: No gain without pain for third culture kids?" International Journal of Multilingualism, 6, 443459. https://doi.org/10.1080/14790710903039906

Fail, H., Thompson, J. and Walker, G. (2004). Belonging, identity and third culture kids." Journal of Research in International Education, 3(3), 319-338. https://doi.org/10.1177/1475240904047358

Furukawa, T. (1997). Sojourner readjustment: Mental health of international students after one year's foreign sojourn and its psychosocial correlates." Journal of Nervous and Mental Disease, 185 (4), 263-268.

https://doi.org/10.1097/00005053-199704000-00007

Gaw, K. (2000). Reverse culture shock in students returning from overseas." International Journal of Intercultural Relations, 24(1), 83-104. https://doi.org/10.1016/S0147-1767(99)00024-3

Gitmez, A. (1983). Yurtdışına İşçi Göçü ve Geri Dönüşler. Istanbul: Alan Yayıncılık.

Gmelch, G. (1980). Return migration. Annual Review of Anthropology, 9, 135 -159.

https://doi.org/10.1146/annurev.an.09.100180.001031

Guzzetta, C. (2004). Return migration. Journal of Immigrant \& Refugee Services,, 2 (1- 2),, 109-17.

https://doi.org/10.1300/J191v02n01_07

Herman, J. and Tetrick, L. (2009). Problem-focused versus emotion-focused coping strategies and repatriation adjustment. Human Resource Management, 48, 69-88. https://doi.org/10.1002/hrm.20267

Huff, J. (2001). Parental attachment, reverse culture shock, perceived social support, and college adjustment of missionary children. Journal of Psychology and Theology, 29 (3), 246-264.

https://doi.org/10.1177/009164710102900307

İçduygu, A. and Kirişci, K. (2009). Land of Diverse Migrations: Challenges of Emigration and Immigration in Turkey. Istanbul: Bilgi University Press.

İçduygu, A. and Sert, D. (2016). "A debate over return migration: The case of Turkish guest workers in Germany." In: D. Leal and N. Rodrigues (eds.), Migration in an Era of Restriction and Recession: Immigrants and Minorities, Politics and Policy (pp.259-72). Springer: Cham.

https://doi.org/10.1007/978-3-319-24445-7_13

Karpat, K. (1985). "The Ottoman emigration to America, 1860-1914.” International Journal of Middle East Studies, 17, 175-209. https://doi.org/10.1017/S0020743800028993

Kaya, A. and Kentel, F. (2005). Euro-Turks: A bridge or a breach between Turkey and the European Union? Bruseels: Center for European Policy Studies.

Kaya, I.. (2004). Turkish-American immigration history and identity formations." Journal of Muslim Minority Affairs, 24 (2), 295-308.

https://doi.org/10.1080/1360200042000296672

Langford, M. (1998). Global nomads, third culture kids and international schools." In M. Hayden and J. Thompson (eds.), International Education: Principles and Practice, (pp. 28- 43). London: Kogan Page.

Linehan, M. and Scullion, H. (2002). Repatriation of female international managers." International Journal of Manpower, 23 (7), 649-658. https://doi.org/10.1108/01437720210450806 
Martin, J. (1984). The intercultural re-entry: Conceptualization and directions for future research. International Journal of Intercultural Relations, 8 (2), 115-34.

https://doi.org/10.1016/0147-1767(84)90035-X

Mazzucato, V.(2007). Return Migration in Ghana: An Overview. Paris: OECD.

Micallef, R. (2004). Turkish Americans: Performing identities in a transnational setting. Journal of Muslim Minority Affairs, 24(2), 233-241. https://doi.org/10.1080/1360200042000296636

Moore, A. and Barker, G. (2012). Confused or multicultural: Third culture individuals' cultural identity. International Journal of Intercultural Relations, $36 \quad$ (4), 553-562. https://doi.org/10.1016/j.ijintrel.2011.11.002

Morgan, L., Nie, W. and Young, S. (2004). Operational factors as determinants of expatriate and repatriate success. International Journal of Operations \& Production Management, 24(12), 1247-68.

https://doi.org/10.1108/01443570410569038

Penninx, R. (1982). A Critical review of theory and practice: The case of Turkey. International Migration Review, 16, 781-818. https://doi.org/10.1177/019791838201600404

Pollock, D. and van Reken, R. (1999). The third culture kid experience: Growing up among worlds. Yarmouth, ME: Intercultural Press.

Presbitero, A. (2016). Culture shock and reverse culture shock: The moderating role of cultural intelligence in international students' adaptation.” International Journal of Intercultural Relations, 53, 28-38.

https://doi.org/10.1016/j.ijintrel.2016.05.004

Rodrigues, C. (2001). International management. St Paul, MN: West Publishing.

Sahin, N. H. (1990). Re-entry and the academic and psychological problems of the second generation." Psychology and Developing Societies, 2(2), 165-182. https://doi.org/10.1177/097133369000200202

Sirkeci, İ. (2005). Diaspora: Turkish. In M. Gibney and R. Hansen (eds.), Immigration and Asylum from 1900 to the Present (pp.607-610). Santa Barbara: ABC-CLIO.

Stroh, L., Gregersen, H. and Black, S. (1998). Closing the Gap: Expectations versus Reality among Repatriates. Journal of World Business, 33(2), 111-24. https://doi.org/10.1016/S1090-9516(98)90001-3

Sussman, N. (2000). The dynamic nature of cultural identity throughout cultural transitions: Why home is not so sweet." Personality and Social Psychology Review, 4(4), 355-373.

https://doi.org/10.1207/S15327957PSPR0404_5

Sussman, N. (2002). Testing the cultural identity model of the cultural transition cycle: Sojourners return home.” International Journal of Intercultural Relations, 26(4), 391-408.

https://doi.org/10.1016/S0147-1767(02)00013-5

Sussman, N. (2007). Identity shifts as a consequence of crossing cultures: Hong Kong Chinese migrants return home.” In K. Chan, J. Walls, and D. Hayward (eds.), East-West Identities: Globalization, Localization, and Hybridization (pp. 121-147). Leiden: Brill. https://doi.org/10.1163/ej.9789004151697.i-404.46

Thompson, C. and Christofi, V. (2006). Can you go home again? A Phenomenological investigation of Cypriot students returning home after studying abroad." International Journal for the Advancement of Counselling, 28(1), 21-39. https://doi.org/10.1007/s10447-005-8493-0

Toktaş, Ş. (2012). Introduction: 50 years of emigration from Turkey to Germany - A success story?" Perceptions 17(2), 5-9.

Useem, R. and Downie., R. (1976). Third culture kids. Today's Education, 65(3), 103-105.

Walters, K. and Auton-Cuff, F. (2009). A story to tell: The identity development of women growing up as third culture kids." Mental Health, Religion and Culture 12(7) 755-772. https://doi.org/10.1080/13674670903029153

Weaver, G. (1993). Understanding and coping with cross-cultural adjustment stress. In M. Paige (ed.), Education for the Intercultural Experience (pp. 193-225). Yarmouth, ME: Intercultural Press.

Yilmaz Sener, M. (2019). Perceived discrimination as a major factor behind return migration? The return of Turkish qualified migrants from the USA and Germany. Journal of Ethnic and Migration Studies, 45:15, 2801-2819, DOI: 10.1080/1369183X.2018.1524292. 


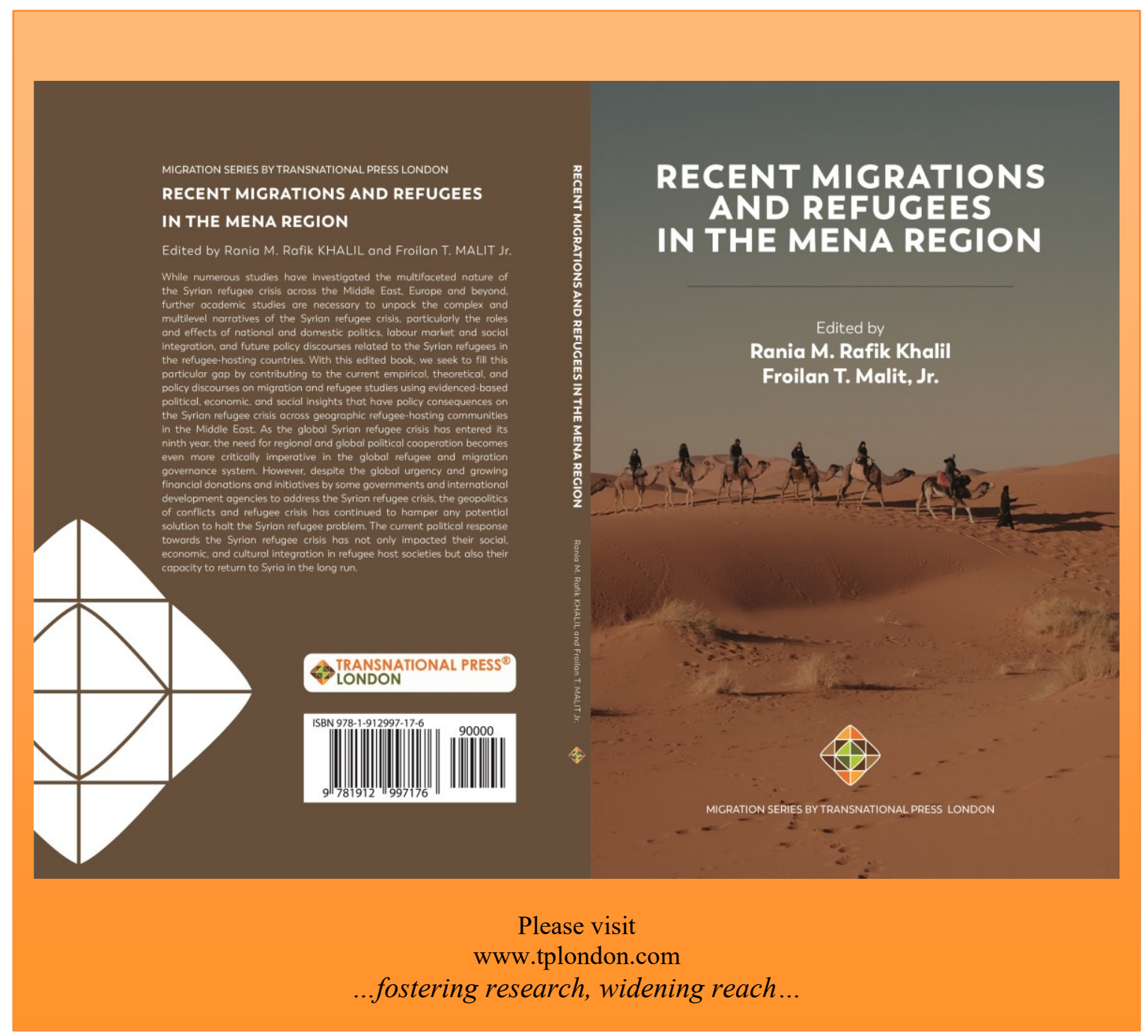

